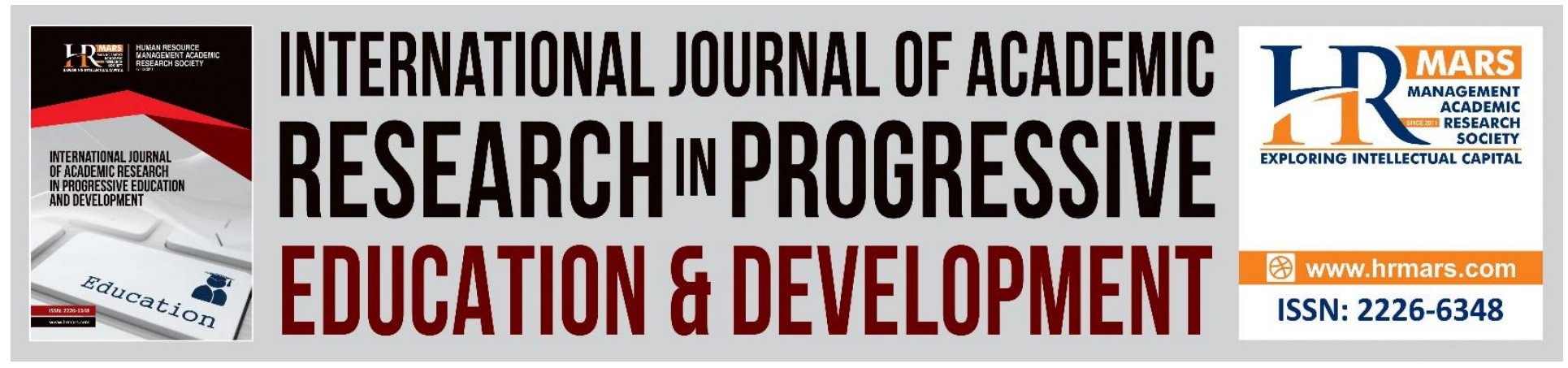

\title{
Exploring and Developing Items Measuring Teachers' Followership Modalities: An Exploratory Factor Analysis Procedure
}

Yeo Siew Pey, Abdul Halim Busari, and Lee Jun Choi

To Link this Article: http://dx.doi.org/10.6007/IJARPED/v10-i1/8945

DOI:10.6007/IJARPED/v10-i1/8945

Received: 16 December 2020, Revised: 20 January 2021, Accepted: 12 February 2021

Published Online: 28 February 2021

In-Text Citation: (Pey et al., 2021)

To Cite this Article: Pey, Y. S., Busari, A. H., \& Choi, L. J. (2021). Exploring and Developing Items Measuring Teachers' Followership Modalities: An Exploratory Factor Analysis Procedure. International Journal of Academic Research in Business and Social Sciences, 10(1), 536-561.

Copyright: (C) 2021 The Author(s)

Published by Human Resource Management Academic Research Society (www.hrmars.com)

This article is published under the Creative Commons Attribution (CC BY 4.0) license. Anyone may reproduce, distribute, translate and create derivative works of this article (for both commercial and non-commercial purposes), subject to full attribution to the original publication and authors. The full terms of this license may be seen at: http://creativecommons.org/licences/by/4.0/legalcode

Vol. 10(1) 2021, Pg. 536 - 561

http://hrmars.com/index.php/pages/detail/IJARPED

JOURNAL HOMEPAGE

Full Terms \& Conditions of access and use can be found at http://hrmars.com/index.php/pages/detail/publication-ethics 


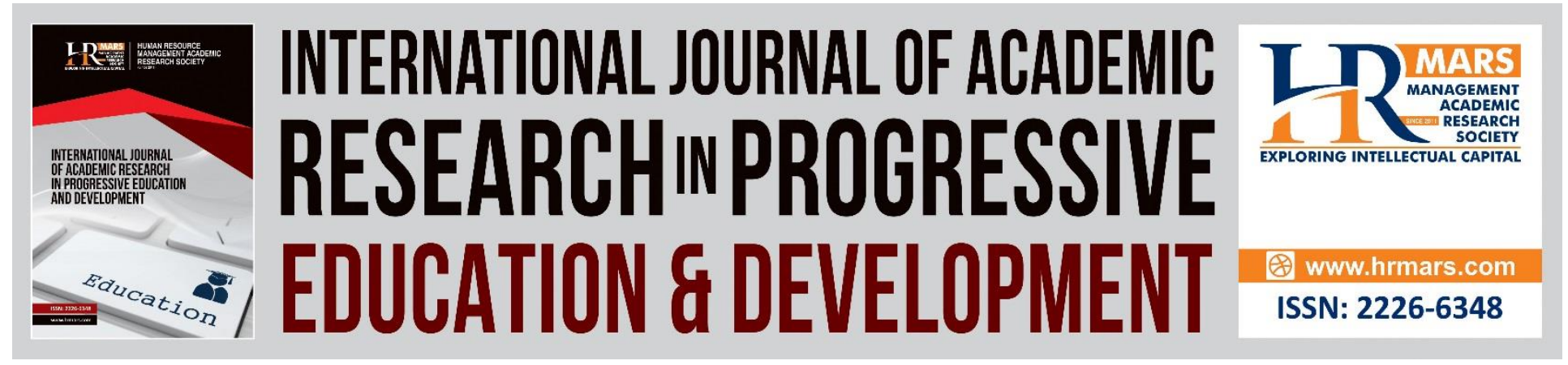

\title{
Exploring and Developing Items Measuring Teachers' Followership Modalities: An Exploratory Factor Analysis Procedure
}

\author{
Yeo Siew Pey, Abdul Halim Busari, and Lee Jun Choi
}

Faculty of Cognitive Sciences and Human Development, Universiti Malaysia Sarawak, 94300 Kota Samarahan, Sarawak, Malaysia.

\begin{abstract}
The concept of followership has received considerable attention over the past three decades. Good followers play crucial role in determining the success of an organization. However, past followership literature has revealed that there is limited understanding of the dimensions that made up followership modalities, especially in the school context. The purpose of the study was therefore to contribute to the existing literature by performing a thorough validation of the dimensions of Teachers' Followership Modalities through the Exploratory Factor Analysis (EFA) procedure. This study used a cross-sectional survey approach to develop precise measurements for the Teachers' Followership Modalities construct. A structured questionnaire in Google Form format was used to collect data. The study included 108 randomly selected public secondary school teachers from three districts in Sarawak, namely Kuching, Padawan, and Samarahan. The study revealed that all 20 items adapted and modified from Kelley's (1992) Followership Questionnaire met the EFA procedure's factor loading cut-off point of .60 using IBM-SPSS software version 25.0. Therefore, all 20 items were kept and deemed appropriate for measuring the Teachers' Followership Modalities construct. However, the EFA procedure disclosed 5 components as compared to Kelley's two-dimensional model. The findings of this study offered a validated and reliable questionnaire to measure Teachers' Followership Modalities among public secondary school teachers in Malaysia. Thus, the Malaysian Ministry of Education which seeks to gain from teachers with good followership modalities will benefit from this research.

Keywords: Followership, Followership Modalities, Teachers, Exploratory Factor Analysis (EFA), Malaysian Public Secondary Schools

\section{Introduction}

Contemporary scholars have widely supported the concept of followership as a thriving proposition which has its independent standpoint. Understanding the reciprocal connection between followers and leaders helps researchers to better construct a followership model (UhlBien et al., 2014; Uhl-Bien \& Arena, 2018). As a result, researchers such as Carsten et al. (2018) begin to define followers as the focus of their research in the field of leadership studies.
\end{abstract}


Apparently, the followership investigation is associated with the behaviours, attitudes, and characteristics of followers that lead to positive outcomes in achieving the organizational goals (Benson, 2018; Chaleff, 2009, 2016; Khan et al., 2019). Kelley's (1992) Followership Model outlined the followers at the workplace should demonstrate exemplary followership modalities (i.e., an independent critical thinker who actively engages) while they specifically contribute to the best organisational outcomes.

The followership modalities were widely measured by Kelley's (1992) followership questionnaire (KFQ) in the field. However, many researchers argued that the KFQ has not been extensively tested and lacks empiric evidence. According to Gatti et al. (2014), the instruments used to determine followership are insufficiently tested and are prone to incredulity. In addition, there is a comparatively limited quantitative study to endorse the followership construct, since only a few qualitative empirical studies have been mentioned and validated in various ways (Crossman \& Crossman, 2011). Ligon et al. (2019) complained that the KFQ was made unclear by using double-barrelled questions in which many items contain two interrelated objects. Moreover, many researchers, such as (Blanchard et al., 2009; Gatti et al., 2014; Ligon et al., 2019; Ribbat et al., 2021) have found that the KFQ measured more than two dimensions as proposed by Kelley. Apart from the vulnerability in its measurement instruments, the researchers also documented limitations in the setting.

Although followership studies have also been performed in different industries, such as banking industry (Ghias \& Hassan, 2018; Ligon et al., 2019), health science sector (Gatti et al., 2014), corporate sector (Ribbat et al., 2021; Rosani \& Tarigan, 2019), there are comparatively limited reports in the school background. Today, schools not only need exemplary leaders but also exemplary followers to take up the responsibility and self-accountability for the success and growth of their niche area. The inclusion of followership neither undermine the importance of preparing leaders for leadership roles nor negates the need to develop leadership skills in all teachers. Unfortunately, followership has not yet included in the standards and guidelines of school leadership curriculum or any teachers' training programs in most of the country, including Malaysia.

This study, therefore, expanded existing findings to the validation of a questionnaire on teachers' followership modalities. The aim of this study is to explore and develop the psychometric properties of the Malaysian version of Kelley's questionnaire for researchers and practitioners to measure the followership modalities among public secondary school teachers. The specific objectives of the study are as follows:

1. To determine the feasible items used to measure the followership modalities that form by an underlying factor structure; and

2. To analyse the reliability and the validity of the factor structure that represents followership modalities among public secondary school teachers.

\section{Literature Review}

\section{Kelley's (1992) Followership Model}

The followership model proposed by Robert Kelley $(1988,1992)$ identifies followers on the basis of behaviours and personality traits. This two-dimensional model focused on Independent Critical Thinking, ICT and Active Engagement, AE which affect the commitment of followers and 
their work performance. Kelley (1992) referred the independent critical thinking dimension as level of followers' thinking. Followers with excellent ability of critical thinking always give constructive criticism independently and innovatively upon the issues at work. Followers mentioned in this dimension are following directions without causing disruption to their leaders or organizations. They are courageous and capable in taking orders from their leader. Oppositely, the worst followers are those who demonstrate reliant and uncritical thinking as they often rely on the strong guidance of their leaders.

The other dimension inclusive in Kelley's (1992) Followership Model is active engagement which explains the level of involvement and interest of the followers in the organizations. Followers who engage actively are relatively constructive, showing a good disposition towards others when they are motivated to do exceptional work. Indeed, these followers exemplify citizenship behaviour. On the opposite spectrum, followers who are less engaged are concerned just to get their work completed. These groups of nasty followers are idle, irresponsible, and consistently demand instruction from their leaders in accomplishing their tasks. In addition to his description, Kelley (1992) developed a measuring instrument in accordance with surveys derived from the measurement of followership dimensions. Kelley classified followers into five different styles of followership, i.e., exemplary, alienated, conformist, pragmatist, and passive (see Table 1).

Table 1. Kelley's (1992) Followership Styles

\begin{tabular}{|c|c|}
\hline Types of Follower & Description \\
\hline Exemplary & $\begin{array}{l}\text { Followers who are independent and able to think critically yet engage } \\
\text { strongly with the group. They provide intelligent challenge and support } \\
\text { to the leader. }\end{array}$ \\
\hline Alienated & $\begin{array}{l}\text { Followers who are independent and able to think critically but do not } \\
\text { willingly obligate to the leader. }\end{array}$ \\
\hline Pragmatist & $\begin{array}{l}\text { Followers who are run-of-the-mill in their independence, engagement, } \\
\text { and general contribution to the leader. }\end{array}$ \\
\hline Conformist & $\begin{array}{l}\text { Followers who are slightly more engaged than passive followers, but do } \\
\text { not pose any challenge to the leader. }\end{array}$ \\
\hline Passive & Followers who do not think critically and hardly participate. \\
\hline
\end{tabular}

To sum up, Kelley's (1992) Followership Model describes five different styles that grounded along two axes: independence of critical thinking (assessed as positive or negative) and engagement (assessed as active or passive). Kelley (1992) indicated that these styles are not rigid, but fluid depending on the circumstance of the follower. This means that a follower can still switch from one style to another or evolve into a distinctly different style. Ideally, Kelley's goal is to have all employees in the workplace adopt an exemplary style (i.e., positive and active) that leads to the best organizational results. Most prominently, Kelley suggested that exemplary followers have a variety of skills (i.e., job, organizational and values) that are learnable where Kelley (1992) presented a justification for the causes of the less favorable types and provided solutions for the transition to exemplary. 
Vol. 10, No. 1, 2021, E-ISSN: $2226-6348$ @ 2021 HRMARS

\section{Evidence on Validation of Kelley's (1992) Followership Questionnaire}

In the light of cultural disparities, different sets of followership measures are preferable for the different ethnic groups. Thus, Kelley's (1992) Followership Model has been validated not only for numerous sectors, but also for diverse national communities, e.g. Canada (Clarke et al., 2015), Serbia (Hinić et al., 2017), Norway (Dahl \& Kongsvik, 2018), and India (Ghias \& Hassan, 2018). This is in line with argument that the unique nature of followership behaviours is accordance to their context culture in countries, industries, companies, and even different sectors of an organization (Blair \& Bligh, 2018; Chaleff, 2016).

Eventually, followership construct is the previous work of Kelley (1992) on corporate sector. Kelley referred to followership behaviors that have been exhibited by followers in their workplace with 20 items that can be categorized under two themes: Independent Critical Thinking, ICT and Active Engagement, AE. However, Blanchard et al. (2009), Gatti et al. (2014) and Ligon et al. (2019) extended Kelley's two-dimensional followership model with an additional dimension, namely Attitude and Affect, AA through their findings. Blanchard et al. (2009) conducted a confirmation analysis with a group of faculty members at a major university in the United States using Kelley's (1992) questionnaire on original English items. Meanwhile, Gatti et al. (2014) used a broad sample of employees $(\mathrm{N}=610)$ from numerous corporate settings to do a validity study for their Italian translation. Ligon et al. (2019) also seeked to examine the validity of their revised Kelley's (1992) Followership Questionnaire for employees from the banking and public utility sectors in United States. Although these studies were performed from various countries, the findings recorded a 3-factor solution with different exploratory factor analysis methods (see Table 2). Notably, Blanchard et al. (2009) argued that Kelley's followership model was based on behavioral theories. Thus, they excluded the third factor in their further analysis. In line with Blanchard et al. (2009); Gatti et al. (2014); Ligon et al. (2019) accepted the recommendation and excluded the four items of the third factor in their entire studies.

Nonetheless, there were also studies that have backed Kelley's (1992) two-dimensional model. Recently, Ribbat et al. (2021) employed the German "SoSci Panel", an online respondent pool focused on voluntary registration, to validate the German version of the KFQ. The findings of the exploratory factor analysis using Mean- And Variance-Adjusted Weighted Least Squares (WLMSV) estimator and Promax rotation revealed a two-factor structure. Despite most of the attempts in Western literature, Rosani and Tarigan (2019) published a review in Indonesia. They also observed that the two variables conceptualized by Kelley (1992) appeared in these findings. However, both studies showed that the items were not loaded unanimously on the two factors as anticipated by Kelley (1992).

Although past research revealed variations in their factor structure, all of the final modified instruments comprised 14 items, except Rosani and Tarigan (2019), which retained all of the 20 items as in the original KFQ version. The reliability of all these items was examined to measure their internal consistency. Blanchard et al. (2009) found that reliabilities for ICT were $\alpha$ $=.74$ while reliabilities for $A E$ were $\alpha=.86$ with a factor correlation of $r=.38, p<.001$. In the Italian version, Gatti et al. (2014) reported the reliabilities of $\alpha=.79$ for ICT and $\alpha=.94$ for AE with a factor correlation of $r=.55, p<.001$. Meanwhile, Ligon et al. (2019) reported a total $\alpha=$ .93 with a factor correlation of $r=.55, p<.001$. Likewise, Ribbat et al. (2021) employed Omega subscale $\left(\omega_{s}\right)$ in German version study. They revealed ICT subscale factor, $\omega_{\text {s }}$ was $.92(95 \% \mathrm{Cl}$ 
土.58); AE subscale factor, $\omega_{\mathrm{s}}$ was $.99(95 \% \mathrm{Cl} \pm .17)$. In the Indonesia version, Rosani and Tarigan (2019) recorded reliabilities of $\alpha=.771$ for ICT and $\alpha=.833$ for AE. The majority of these past studies seem to surpass the acceptable level of reliability $(\alpha>.70)$ with AE showed a higher level of reliability as compared to ICT in general.

Notwithstanding the reliability results, Gatti et al. (2014), Ribbat et al. (2021) and Rosani and Tarigan (2019) further validated the scale with confirmatory factor analysis (CFA). Gatti et al. (2014) reported a model fit of $\chi 2(73)=296.66, p<.001, \chi 2 / d f=3.90$, Comparative Fit Index $(\mathrm{CFI})=.96$, Root Means Square Error of Approximation (RMSEA)=.10, and Standard Root Mean Residual $(\mathrm{SRMR})=.07$, and Goodness of Fit Index $(\mathrm{GFI})=.88$ for a two-factorial solution while Ribbat et al. (2021) reported their fit indexes, $\chi 2(76)=240.63, p<.001, \chi 2 / d f=3.17, \mathrm{RMSEA}=.10$, $\mathrm{CFI}=.94, \mathrm{WRMR}=.96$. On the other hand, Rosani and Tarigan (2019) reported RMSEA=.065, $\mathrm{SRMR}=.046, \mathrm{GFI}=.901$, and $\mathrm{CFI}=.885$. The findings for the past studies are summarized in Figure 1.

With refer to the previous studies, the researcher acknowledged the need to validate a modified and translated measurement in order to assess the teachers' followership modalities. To the best of the researchers' knowledge, this is the first attempt to investigate the validity and reliability of followership modalities measurement among Malaysian public secondary school teachers. 


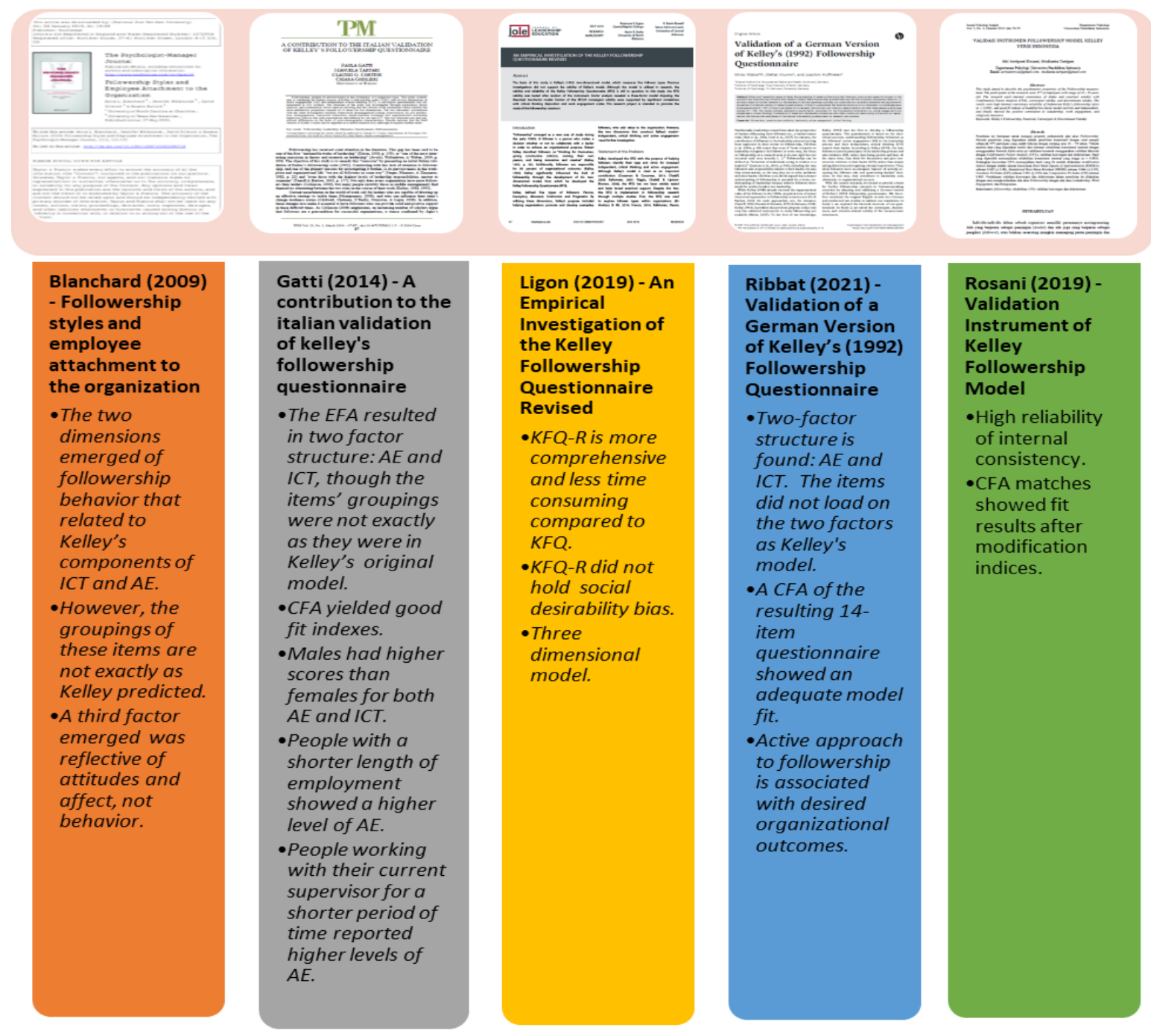

Figure 1. Summary of Findings from Evidence on Validation of Kelley's (1992) Followership Questionnaire

\section{Research Methodology Research Design}

This study has adopted a cross-section quantitative approach. Surveys provide valuable information to explain patterns among a wide range of people (Creswell \& Guetterman, 2019). The survey was structured to generalize the findings of the study to the population and to draw strong and valid conclusions (Creswell \& Guetterman, 2019). The questionnaire was used in this study due to its ability to rapidly collect quantified data within a limited timeframe. Thus, this study entailed the self-administered questionnaire to gather data on the perceptions of public secondary school teachers in Malaysia on their followership modalities. 
DEVELOPMENT

Vol. 10, No. 1, 2021, E-ISSN: 2226-6348 @ 2021 HRMARS

\section{Population and Sampling Procedures}

A pilot study using the pilot questionnaire was conducted for this study, where the main purpose was to determine the feasibility and adequacy of the instrument used for the field study. After this, the Exploratory Factor Analysis (EFA) is employed as a start point to explore the factor structures of the instrument. The 'Rule of 100 ' is followed where a minimum sample size to run EFA must be at least 100 participants (Gorsuch, 1990; Hair et al., 2014; MacCallum et al., 1999). This study used a sample size of $\mathrm{N}=108$ to run the EFA analysis.

The unit of analysis examined in this current study refers to individual teachers in public secondary schools in Sarawak. The target population of this pilot study comprised of certified public secondary school teachers who served in the three District Education Office (DEO), i.e., Kuching, Padawan and Samarahan in Sarawak. The sampling frame for this study is a randomly selected public secondary school teacher based in three Sarawak DEO. The full list of public secondary schools situated in the three districts was collected from the Sarawak State Department of Education (as of 28th December 2020). Five public secondary schools were randomly selected for each of the DEO with a random selection generator tool (Weblink: https://www.dcode.fr/random-selection). The researchers had also set the inclusion criteria for the respondents as certified teachers who had been serving with the current school principals for more than 2 years in order to gather more reliable evidence. Ten respondents per school were selected randomly using the same tool. Self-administrative questionnaires were distributed through Google Form to 150 samples of teachers in the population using simple random sampling. Therefore, the entire 150 teachers are representatives of public secondary school teachers in Malaysia.

\section{Research Instrument}

The standardised questionnaire from Kelley's (1992) Followership Questionnaire was tailored to fit the context of this study to obtain data on the appropriate measures of the Teachers' Followership Modalities among Malaysian public secondary school teachers. The 20 items in the questionnaire were presented on a 10-point interval scale ranging from " 1 = Strongly Disagree" to "10 = Strongly Agree". The first construct, i.e., Independent Critical Thinking, ICT was measured using 10-item measure which covers the level of critical thinking of the teachers. A sample item is "I reflect on my strengths and weaknesses." Similarly, the second construct, i.e., Active Engagement, AE was assessed using a 10-item measure which covers the level of engagement of the teachers in school. A sample item is "I am enthusiastic about my work."

\section{Data Collection}

The use of electronic and online questionnaires appears to be the most appropriate strategy for collecting the desired data for this study, particularly during the period of the COVID-19 pandemic, which restricts the movement of researchers. In fact, online questionnaires are often used to gain an understanding of respondents' preferences (Sekaran \& Bougie, 2016). The Google link of the questionnaire sent to the respondents via Telegram or WhatsApp enables the respondents to complete the Google Form at their convenience. In addition, the automated and real-time processing of the survey would save extra costs, time, and resources (Sekaran \& Bougie, 2016). This study has followed a few principles to ensure ethical conduct, such as the 
implementation of voluntary participation, anonymity, and confidentiality, and to give research information to respondents (Sekaran \& Bougie, 2016). Apart from that, keeping the questionnaire short and precise, as well as sending a soft-reminder message, are some useful tips that help to increase response rates.

Before the distribution of the questionnaire, the researchers had obtained authorization from the Educational Planning and Research Department (EPRD) of Malaysia's Ministry of Education, Sarawak State Education Department, and school principals from the participating schools. At each school, the Google Form link was distributed to teachers who are selected randomly with referred to their school's name lists. The survey was administered in January 2021 with Google Form and had completed within one week. As a result, 108 teachers from the total sample of 150 had responded to the Google Form. This excellent response rate $(72 \%)$ is likely driven by the high degree of commitment of the teachers to complete the survey.

\section{Data Analysis}

\section{Descriptive Analysis}

Researchers typically show some particulars of interest as a description of the respondent composition (Huff \& Tingley, 2015). Descriptive statistics, such as percentage, frequency count, mean and standard deviation, were used to describe the socio-demographic profile of the respondents as well as the measurement-level effects of the 20-item Teachers' Followership Modalities.

\section{Pre-Test and Pilot-Test}

Many researchers recommended that a pre-test and pilot-test should be undertaken to verify that the modified instrument, particularly when this original instrument was established in different cultures and industries than the current study (Hoque et al., 2018; Muda et al., 2020; Rahlin et al., 2019). Thus, content validity, face validity, and criterion validity were employed as a pre-test for this current study.

The content validity of the modified instrument was reviewed by three experts: two senior lecturers from local universities and a School Improvement Partner+ (SIP) coach who holds a PhD degree. These experts concluded that the instrument contains all the necessary components and removes unfavorable items in a specific construct (Lewis et al., 1995, Boudreau et al., 2001). Since the measurement items were originally developed in English, they have been translated into Bahasa Melayu and reviewed using the back-translation procedures as recommended by Brislin (1970) and Triandis and Brislin (1984). As such, two experienced English and Bahasa Melayu language teachers approached the face validity issue in order to validate whether the items in the questionnaire seem to be appropriate, unambiguous and relevant (Oluwatayo, 2012). Meanwhile, a statistician professor checked the criterion validity to ensure that the scales used to measure how accurately one measure forecasts the outcome of another measure are correct (Taherdoost, 2016b, 2016a).

Next, the questionnaire was reviewed and revised in compliance with the experts' guidelines prior to design in Google Form format. The researcher then pre-tested the updated questionnaire in Google Form format with five public secondary school teachers to get their feedback on its consistency and validity, as well as to determine the uniformity of their responses 
and find any technical problems with the Google Form edition. Upon completion of the pretesting process, the researcher amended the item statement based on the reviewers' comments. The researcher subsequently circulated the latest update questionnaire to the respondents to collect at least 100 responses for the pilot study's exploratory factor analysis (EFA).

Many researchers widely accepted that the validity of the instrument could be enhanced by a pilot test (Hair et al., 2015; Nunnally \& Bernstein, 1994). In social science studies, the term pilot study is used in two distinct ways, studies that are "small scale version(s) or trial run(s), done in preparation for the major study" (Polit et al., 2001, p.467). Some researchers, such as van Teijlingen and Hundley (2002), articulated that well-designed and well-managed pilot studies could inform us of the proper research procedure and, possibly, the potential outcomes. Researchers are therefore urged to report on their pilot studies and, most critically, to report in more depth on the particular changes made to the nature of the project and the research process. Hence, the researcher used the pilot study to identify areas with a shortcoming in the current survey.

\section{Exploratory Factor Analysis (EFA)}

Factor analysis is known to be a multivariate statistical procedure for the evaluation of selfreported questionnaires. Factor analysis is commonly used in various areas of study, e.g., social sciences, economics, geography (Yong \& Pearce, 2013), psychology, education, and medicine (Williams et al., 2010), as a result of information technology advances. As prominent scholars in this field, Hair et al. (2014) concluded that the major purpose of the factor analysis is to establish the fundamental structure of the variables in the analysis. In the same vein, Williams et al. (2010) suggested that exploratory factor analysis (EFA) is widely used for three purposes in a nuanced manner. First, factor analysis reduces the number of factors to a smaller number of factors containing representative items of each construct or variable (Hair et al., 2014; Mahfouz et al., 2019). Second, factor analysis establishes fundamental dimensions between measurable variables and latent constructs which facilitating the development and refinement of theory. Third, factor analysis offers proof of the construct validity of self-reporting measurements (Nunnally, 1978). Since the factors of latent constructs can only be measured implicitly, a group of items is required to measure them. Therefore, the EFA should be undertaken to examine the dimensionality of items that may differ from previous studies due to suitability and usefulness in the research context (Hair et al., 2010). In the context of this study, the researcher employed the EFA to verify the number of specific components or dimensions of the Teachers' Followership Modalities instrument and the pattern of the item-factor loadings.

With examining the appropriateness of the data to run factor analysis, the Kaiser-Meyer Olkin (KMO) measure and Bartlett's Test of Sphericity were used. The KMO test was employed to determine the adequacy of sample size while Bartlett's test can estimate the possibility of factor analysis stability. In this study, a KMO value > 0.60 (Kaiser, 1974; Pallant, 2016; Tabachnick \& Fidell, 2013) and a statistically significant Bartlett's Test of Sphericity (Bartlett, 1950) were referred to indicate the data factorability. If the significance value of Bartlett's Test is close to $0.00(p<0.05)$, the items are deemed appropriate for carrying out a factor analysis (Awang, 2012). The construct validity and suitability of the instrument were then determined within the context of the Malaysian public secondary schools. 
In performing EFA, the procedures of Principal Component Analysis (PCA) with Varimax rotation (Gaskin \& Happell, 2014) were applied to data from the 108 school teachers. The Varimax rotation was chosen since the factors were independent of each other. Rotation aims to simplify the factor structure of a group of items or, in other words, high item loads on one factor and smaller item loads on the remaining factor solutions. On the other hand, PCA is highly recommended to determine the preliminary solutions in the EFA (Pett et al., 2003). However, the use of PCA is based on a few circumstances. First, the eigenvalue of the factors must be greater than 1 . Second, items should meet a factor loading exceeding 0.50 for practical significance. Third, items with cross-loading higher than 0.50 should be rejected. Nevertheless, this study had opted to keep only items with factor loadings greater than 0.60 since the items were initially adapted from a pool of established items (Awang, 2012). Forth, the retained factor must consist of at least three items (Hair et al., 2010). Additionally, the number of factors retained can be identified concerning the scree plot (Cattell, 1966). Steps of the EFA protocol for the Teachers' Followership Modalities construct are depicted in Figure 2. After a comprehensive data cleaning and screening process, the 108 responses were found to be valid and subsequently analyzed using IBM-SPSS software version 25.0.

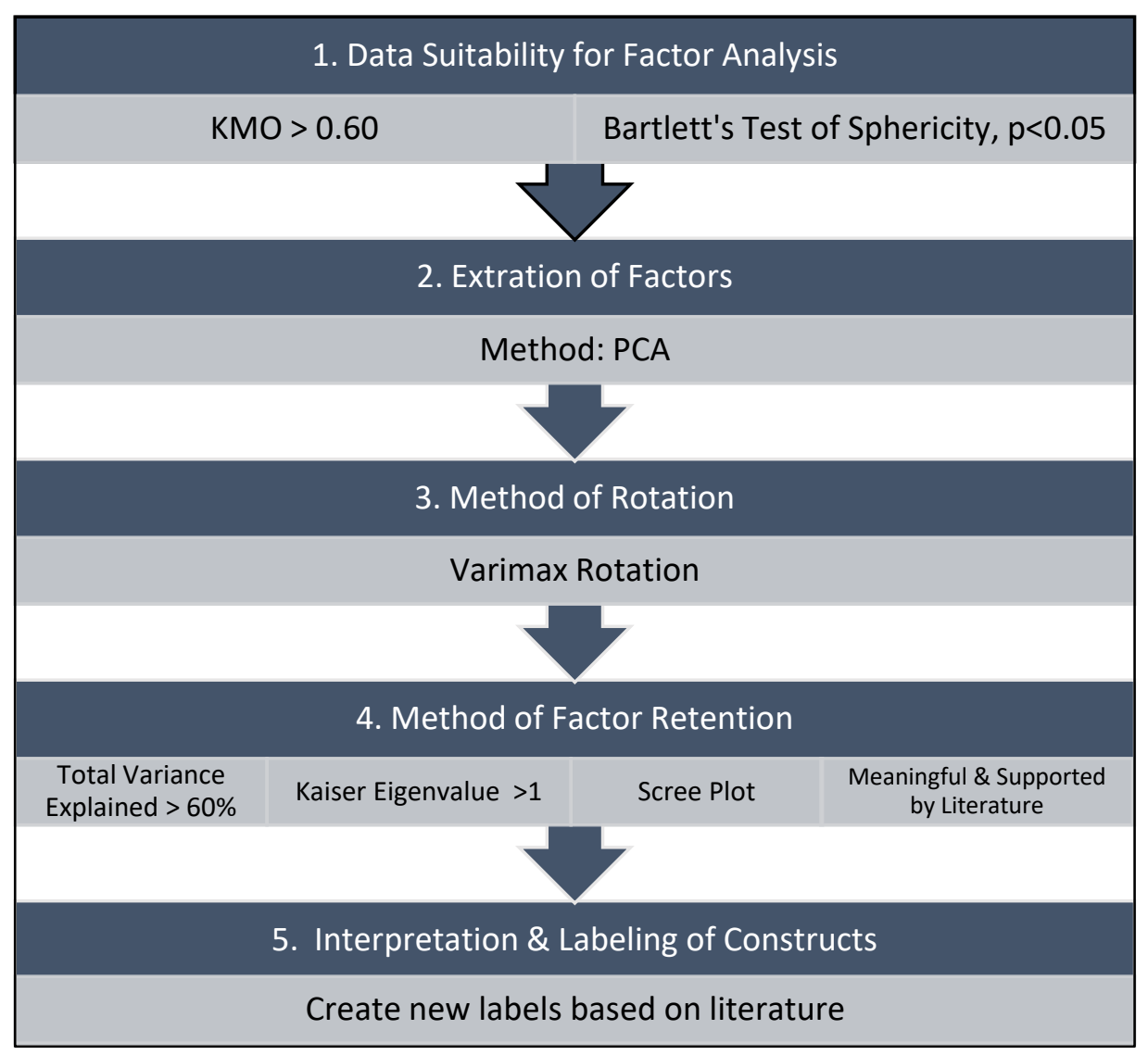

Figure 2. The Five-Steps Exploratory Factor Analysis Protocol (adapted and modified from Williams et al. (2010)) 
INTERNATIONAL JOURNAL OF ACADEMIC RESEARCH IN PROGRESSIVE EDUCATION AND

DEVELOPMENT

Vol. 10, No. 1, 2021, E-ISSN: 2226-6348 @ 2021 HRMARS

\section{Reliability Analysis}

Reliability refers to the degree to which the test scores are consistent and are not influenced by various uncontrollable factors, such as the set of structural questions, the selection of the participants, the time and location of the test (Livingston, 2018). According to Sekaran and Bougie (2016), a construct or variable is reliable if it can consistently measure the concept it is intended to test without bias. The test is thus considered reliable if it is capable to reduce the causes of inconsistency or error of measurement such that the error is not strongly correlated with the true score. Apparently, there are different methodological approaches used for estimating different forms of reliability, such as test-retest, interrater and internal consistency.

Internal consistency reliability is an indicator of how consistent the findings are over the test items of the same construct. In the range of indexes, Cronbach's $\alpha$ is the most widely used measure to assess the internal consistency of an instrument. Correspondingly, the internal consistency reliability of the Teachers' Followership Modalities construct in this current study was estimated using the Cronbach's $\alpha$ coefficient. This coefficient is eventually a measure of the correlation between observed scores and true scores. Cronbach's $\alpha$ result is a number between 0 and 1 . To achieve high internal reliability, Cronbach's $\alpha$ should be greater than 0.70 for the items (Heale \& Twycross, 2015; Nunnally, 1978; Rovai et al., 2014). However, a general accepted rule is that $\alpha$ of 0.6-0.7 indicates an acceptable level of reliability, and 0.8 or greater a very good level. Nonetheless, reliability values higher than 0.95 are not desirable, since they might be an indication of redundancy and hence unlikely to be a valid measure of the construct (Hair et al., 2019; Hulin et al., 2001). As for an exploratory or pilot study, Straub and Gefen (2004) suggested that reliability should be equal to or above 0.60. Meanwhile, Hinton et al. (2014) have suggested four cut-off points for reliability, which includes excellent reliability ( 0.90 and above), high reliability (0.70-0.90), moderate reliability $(0.50-0.70)$ and low reliability $(0.50$ and below).

In conclusion, the concepts of reliability and validity are used to determine the performance of research. They describe the precision of which a procedure, methodology, or test measure thing. Validity is concerned with a measure's accuracy, while reliability is concerned with its consistency. Since test scores cannot be valid for any reason unless they are reliable, both reliability and validity are equally important.

\section{Results}

\section{Descriptive Statistics for the Socio-demographic Variables}

Some of the essential socio-demographic information of the respondents, such as school location, gender, age, ethnicity, education level, teaching experience, years of service in the current school, years of service with the current school principal, and average time engaged with school principal per week (physically and/or virtually) of the 108 useable responses have been examined and presented in this current study. The results are presented in Table 2. 
INTERNATIONAL JOURNAL OF ACADEMIC RESEARCH IN PROGRESSIVE EDUCATION AND

DEVELOPMENT

Vol. 10, No. 1, 2021, E-ISSN: $2226-6348$ @ 2021 HRMARS

Table 2. Socio-demographic Information of Respondents

\begin{tabular}{|c|c|c|c|c|}
\hline No & Socio-demographic & bles & Frequency & Percentage \\
\hline \multirow[t]{3}{*}{1} & \multirow[t]{3}{*}{ Location } & Kuching & 34 & 31.5 \\
\hline & & Padawan & 38 & 35.2 \\
\hline & & Samarahan & 36 & 33.3 \\
\hline \multirow[t]{2}{*}{2} & \multirow[t]{2}{*}{ Gender } & Male & 38 & 35.2 \\
\hline & & Female & 70 & 64.8 \\
\hline \multirow[t]{4}{*}{3} & \multirow[t]{4}{*}{ Age } & $<30$ years & 11 & 10.2 \\
\hline & & $30-39$ & 34 & 31.5 \\
\hline & & $40-50$ & 36 & 33.3 \\
\hline & & $>50$ & 27 & 25.0 \\
\hline \multirow[t]{4}{*}{4} & \multirow[t]{4}{*}{ Ethnicity } & Malay & 31 & 28.7 \\
\hline & & Chinese & 46 & 42.6 \\
\hline & & $\begin{array}{l}\text { Native } \\
\text { Sarawak/Sabah }\end{array}$ & 28 & 25.9 \\
\hline & & Indian & 3 & 2.8 \\
\hline \multirow[t]{4}{*}{5} & \multirow[t]{4}{*}{ Education level } & Diploma & 2 & 1.9 \\
\hline & & Bachelor & 87 & 80.6 \\
\hline & & Master & 19 & 17.6 \\
\hline & & Ph.D. & 0 & 0.0 \\
\hline \multirow[t]{3}{*}{6} & \multirow[t]{3}{*}{ Teaching experience } & $<5$ years & 13 & 12.0 \\
\hline & & $5-16$ & 41 & 38.0 \\
\hline & & $>16$ & 54 & 50.0 \\
\hline \multirow[t]{3}{*}{7} & \multirow[t]{3}{*}{ Years of service in the current school } & $<5$ years & 31 & 28.7 \\
\hline & & $5-16$ & 51 & 47.2 \\
\hline & & $>16$ & 26 & 24.1 \\
\hline \multirow[t]{3}{*}{8} & \multirow{3}{*}{$\begin{array}{l}\text { Years of service with current school } \\
\text { principal }\end{array}$} & $<5$ years & 89 & 82.4 \\
\hline & & $5-16$ & 19 & 17.6 \\
\hline & & $>16$ & 0 & 0.0 \\
\hline \multirow[t]{3}{*}{9} & \multirow{3}{*}{$\begin{array}{l}\text { Average time engaged with school } \\
\text { principal per week (physically and/or } \\
\text { virtually) }\end{array}$} & $<30$ minutes & 55 & 50.9 \\
\hline & & $30-60$ & 32 & 29.6 \\
\hline & & $>60$ & 21 & 19.4 \\
\hline
\end{tabular}

\section{Descriptive Statistics for the Factor Structure}

In this study, the Teachers' Followership Modalities construct was measured using 20 items in the self-reported questionnaire with the interval score from $1=$ Strongly Disagree to $10=$ Strongly Agree. Awang et al. (2016) affirmed that the 10-point interval scale is more reliable compared to the 5-point scale in the measurement model due to the larger option and more flexibility. Initially, the Teachers' Followership Modalities construct was measured by two dimensions: (1) Independent Critical Thinking, ICT and (2) Active Engagement, AE. Item 1 to 10 are measuring ICT while Item 11 to 20 are measuring AE. The statements of each item and their coding as F1 to F20 are demonstrated in Table 3. Meanwhile, the descriptive statistics in Table 3 also revealed 
INTERNATIONAL JOURNAL OF ACADEMIC RESEARCH IN PROGRESSIVE EDUCATION AND

DEVELOPMENT

Vol. 10, No. 1, 2021, E-ISSN: 2226-6348 @ 2021 HRMARS

the mean value for the items of the Teachers' Followership Modalities construct which ranged from 6.52 to 9.43 and the standard deviation value which ranged from 0.800 to 1.963 .

Table 3. The Descriptive Statistics of Measurement Items of Teachers' Followership Modalities Construct

\begin{tabular}{|c|c|c|c|}
\hline Item & Statement & Mean & $\begin{array}{c}\text { Std. } \\
\text { Deviation } \\
\text { a }\end{array}$ \\
\hline F1 & Teaching is an important goal for me & 9.43 & .871 \\
\hline $\mathrm{F} 2$ & $\begin{array}{l}\text { I independently identify which school activities are most critical in } \\
\text { achieving the school's goals }\end{array}$ & 8.47 & 1.250 \\
\hline F3 & $\begin{array}{l}\text { I independently think of ideas that will contribute significantly to the } \\
\text { school's goals }\end{array}$ & 8.14 & 1.313 \\
\hline F4 & I reflect on my strengths and weaknesses & 8.81 & .988 \\
\hline F5 & I act based on my own ethical standards rather than on others' & 7.93 & 1.692 \\
\hline F6 & $\begin{array}{l}\text { I try to solve the work-related issues on my own rather than seek help } \\
\text { from my principal }\end{array}$ & 7.98 & 1.542 \\
\hline F7 & I help my principal to identify the pros and cons of ideas & 7.33 & 1.578 \\
\hline F8 & I ponder my principal's decisions & 6.52 & 1.963 \\
\hline F9 & $\begin{array}{l}\text { When the principal asks me to do something that contradicts my } \\
\text { professional preferences, I say "no" rather than "yes" }\end{array}$ & 7.37 & 1.936 \\
\hline F10 & $\begin{array}{l}\text { I assert my views on important issues even though it may differ from } \\
\text { my principal's }\end{array}$ & 7.48 & 1.456 \\
\hline F11 & My work goals are in line with the school's goals & 8.88 & .964 \\
\hline F12 & I am committed to my school & 9.26 & .800 \\
\hline F13 & I am enthusiastic about my work & 9.23 & .883 \\
\hline F14 & $\begin{array}{l}\text { I actively develop my teaching competencies so that I become more } \\
\text { valuable to the school }\end{array}$ & 8.95 & .993 \\
\hline F15 & $\begin{array}{l}\text { I can complete a difficult assignment (e.g., teaching, project, } \\
\text { committee, etc.) without supervision }\end{array}$ & 8.77 & 1.076 \\
\hline F16 & $\begin{array}{l}\text { When I start a new task at school (e.g., teaching, project, committee, } \\
\text { etc.), I consider outcomes that are important to the school }\end{array}$ & 8.64 & 1.006 \\
\hline F17 & $\begin{array}{l}\text { I take the initiative to pursue tasks beyond my routine job (e.g., Parent- } \\
\text { Teacher Association) }\end{array}$ & 7.38 & 1.794 \\
\hline F18 & $\begin{array}{l}\text { Even though I may not be the leader of a project, I continue to } \\
\text { contribute to my best ability }\end{array}$ & 8.79 & 1.006 \\
\hline F19 & $\begin{array}{l}\text { I help my colleagues, even when I am not receiving recognition for } \\
\text { doing so }\end{array}$ & 8.92 & 1.057 \\
\hline F20 & I understand the principal's goals for the school & 8.79 & .961 \\
\hline
\end{tabular}


Vol. 10, No. 1, 2021, E-ISSN: 2226-6348 @ 2021 HRMARS

\section{Results for Exploratory Factor Analysis (EFA)}

The Kaiser-Meyer-Olkin (KMO) value was 0.792, which was greater than the recommended threshold value of 0.6 (Kaiser, 1974; Pallant, 2016; Tabachnick \& Fidell, 2007). This indicated that the sample of the study was adequate and that the data was suitable for this type of analysis. Besides, Bartlett's Test of Sphericity was also significant (Chi-square=1277.597, p-value<.001), indicating that there were enough correlations between the variables to proceed with the analysis (Meyers et al., 2013). Both the values, therefore, demonstrated that the data obtained is acceptable to conduct the data reduction procedure (Hoque et al., 2018; Shkeer \& Awang, 2019) (see Table 4).

Table 4. The KMO and Bartlett's Test of Sphericity for Teachers' Followership Modalities Construct

\begin{tabular}{|l|l|l|}
\hline \multicolumn{3}{|c|}{ KMO and Bartlett's Test } \\
\hline Kaiser-Meyer-Olkin Measure of Sampling Adequacy & .792 \\
\hline \multirow{3}{*}{$\begin{array}{l}\text { Bartlett's Test of } \\
\text { Sphericity }\end{array}$} & Approx. Chi-Square & 1277.5 \\
& df & 97 \\
\hline & Sig. & 190 \\
\hline
\end{tabular}

\section{The Components and Total Variance Explained}

The EFA procedure was conducted using Principal Component Analysis (PCA) with Varimax Rotation on the 20 items that measuring the Teachers' Followership Modalities construct. Table 5 shows the PCA with Varimax rotation results for 20 items under Teachers' Followership Modalities construct. In reference to the Eigenvalue greater than 1.0, there are five components extracted with the eigenvalues ranged from 1.067 to 7.966 . Furthermore, for measuring the Teachers' Followership Modalities construct, the total variance explained is $74.376 \%$. This value has exceeded the minimum requirement of $60 \%$ for a valid construct (Awang et al., 2015; Yahaya et al., 2018). The results showed that the variance explained in Component 1 to Component 5 was $39.830 \%, 12.316 \%, 8.797 \%, 8.098 \%$ and $5.336 \%$ (see Table 5).

Table 5. The Components and Total Variance Explained for Teachers' Followership Modalities Construct

\begin{tabular}{ccccccc}
\hline \multirow{2}{*}{$\begin{array}{c}\text { Componen } \\
\mathrm{t}\end{array}$} & \multicolumn{3}{c}{ Initial Eigenvalues } & \multicolumn{2}{c}{ Extraction Sums of Squared Loadings } \\
\cline { 2 - 6 } & Total & $\begin{array}{c}\% \text { of } \\
\text { Variance }\end{array}$ & $\begin{array}{c}\text { Cumulative } \\
\%\end{array}$ & Total & $\begin{array}{c}\text { \% of } \\
\text { Variance }\end{array}$ & $\begin{array}{c}\text { Cumulative } \\
\%\end{array}$ \\
\hline 1 & 7.966 & 39.830 & 39.830 & 7.966 & 39.830 & 39.830 \\
2 & 2.463 & 12.316 & 52.146 & 2.463 & 12.316 & 52.146 \\
3 & 1.759 & 8.797 & 60.943 & 1.759 & 8.797 & 60.943 \\
4 & 1.620 & 8.098 & 69.040 & 1.620 & 8.098 & 69.040 \\
5 & 1.067 & 5.336 & 74.376 & 1.067 & 5.336 & 74.376 \\
\hline
\end{tabular}

Extraction Method: Principal Component Analysis 
Vol. 10, No. 1, 2021, E-ISSN: 2226-6348 @ 2021 HRMARS

Figure 3 illustrates that the EFA procedure has disclosed five components for the Teachers' Followership Modalities construct. The 20 items were neatly categorized into five distinct components by the EFA procedure. After the fifth factor, the scree plot clearly displays an apparent point of inflation. Each component consists of a few items, and the rotated component matrix depicts how the items are clustered.

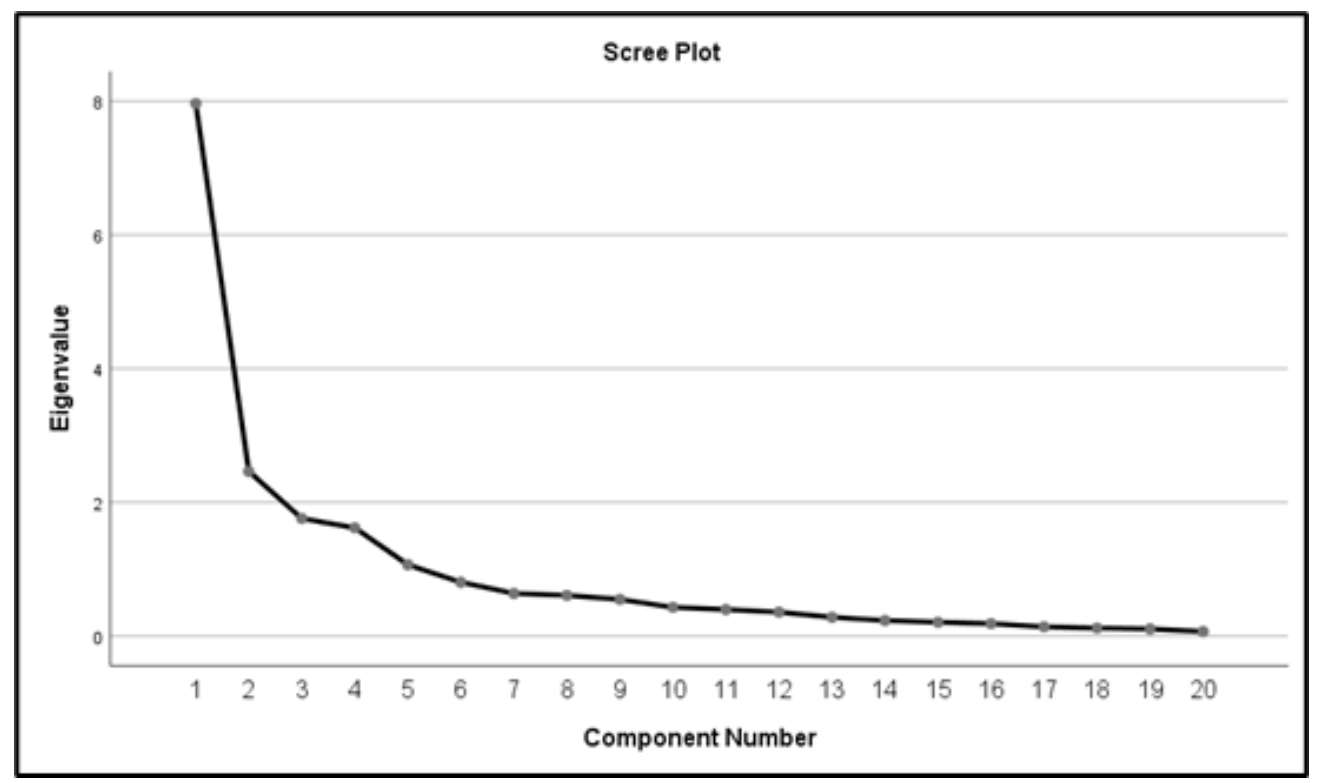

Figure 3. The Scree Plot for Teachers' Followership Modalities Construct

The rotated component matrix results for the Teachers' Followership Modalities construct suggested a 5-component solution. There were no cross-loadings of items among the five components. Hence, the results allowed the study to use the five components as compared to the two components in the literature. Table 6 lists the five components and related items. The factor loading for all items is higher than .60. Therefore, all the 20 items were kept and claimed adequate to measure the Teachers' Followership Modalities construct. 
INTERNATIONAL JOURNAL OF ACADEMIC RESEARCH IN PROGRESSIVE EDUCATION AND

DEVELOPMENT

Vol. 10, No. 1, 2021, E-ISSN: 2226-6348 @ 2021 HRMARS

Table 6. The Five Components and Their Related Items

\begin{tabular}{|c|c|c|c|c|c|c|}
\hline \multicolumn{7}{|c|}{ Rotated Component Matrix ${ }^{a}$} \\
\hline \multirow{2}{*}{$\begin{array}{l}\text { Item } \\
\text { Labe } \\
\text { I }\end{array}$} & \multirow[b]{2}{*}{ Item Statement } & \multicolumn{5}{|c|}{ Component } \\
\hline & & 1 & 2 & 3 & 4 & 5 \\
\hline F1 & Teaching is an important goal for me & .797 & & & & \\
\hline F2 & $\begin{array}{l}\text { I independently identify which school activities are } \\
\text { most critical in achieving the school's goals }\end{array}$ & & & $\begin{array}{l}.74 \\
6\end{array}$ & & \\
\hline F3 & $\begin{array}{l}\text { I independently think of ideas that will contribute } \\
\text { significantly to the school's goals }\end{array}$ & & & $\begin{array}{l}.78 \\
1\end{array}$ & & \\
\hline F4 & I reflect on my strengths and weaknesses & .626 & & & & \\
\hline F5 & $\begin{array}{l}\text { I act based on my own ethical standards rather than } \\
\text { on others' }\end{array}$ & & & & $\begin{array}{l}.71 \\
7\end{array}$ & \\
\hline F6 & $\begin{array}{l}\text { I try to solve the work-related issues on my own } \\
\text { rather than seek help from my principal }\end{array}$ & & & & $\begin{array}{l}.71 \\
1\end{array}$ & \\
\hline F7 & $\begin{array}{l}\text { I help my principal to identify the pros and cons of } \\
\text { ideas }\end{array}$ & & & $\begin{array}{l}.69 \\
0\end{array}$ & & \\
\hline F8 & I ponder my principal's decisions & & & & $\begin{array}{l}.73 \\
1\end{array}$ & \\
\hline F9 & $\begin{array}{l}\text { When the principal asks me to do something that } \\
\text { contradicts my professional preferences, I say "no" } \\
\text { rather than "yes" }\end{array}$ & & & & & $\begin{array}{l}.76 \\
7\end{array}$ \\
\hline F10 & $\begin{array}{l}\text { I assert my views on important issues even though } \\
\text { they may differ from my principal's }\end{array}$ & & & & & $\begin{array}{l}.71 \\
1\end{array}$ \\
\hline F11 & My work goals are in line with the school's goals & .602 & & & & \\
\hline F12 & I am committed to my school & .792 & & & & \\
\hline F13 & I am enthusiastic about my work & .837 & & & & \\
\hline F14 & $\begin{array}{l}\text { I actively develop my teaching competencies so that } \\
\text { I become more valuable to the school }\end{array}$ & .820 & & & & \\
\hline F15 & $\begin{array}{l}\text { I can complete a difficult assignment (e.g., teaching, } \\
\text { project, committee, etc.) without supervision }\end{array}$ & & & & & $\begin{array}{l}.63 \\
0\end{array}$ \\
\hline F16 & $\begin{array}{l}\text { When I start a new task at school (e.g., teaching, } \\
\text { project, committee, etc.), I consider outcomes that } \\
\text { are important to the school }\end{array}$ & & $\begin{array}{l}.70 \\
2\end{array}$ & & & \\
\hline F17 & $\begin{array}{l}\text { I take the initiative to pursue tasks beyond my } \\
\text { routine job (e.g., Parent-Teacher Association) }\end{array}$ & & & $\begin{array}{l}.67 \\
3\end{array}$ & & \\
\hline F18 & $\begin{array}{l}\text { Even though I may not be the leader of a project, I } \\
\text { continue to contribute to my best ability }\end{array}$ & & $\begin{array}{l}.83 \\
8\end{array}$ & & & \\
\hline F19 & $\begin{array}{l}\text { I help my colleagues, even when I am not receiving } \\
\text { recognition for doing so }\end{array}$ & & $\begin{array}{l}.85 \\
1\end{array}$ & & & \\
\hline F2O & I understand the principal's goals for the school & & $\begin{array}{l}.75 \\
2\end{array}$ & & & \\
\hline
\end{tabular}


Vol. 10, No. 1, 2021, E-ISSN: 2226-6348 @ 2021 HRMARS

\section{Extraction Method: Principal Component Analysis}

Rotation Method: Varimax with Kaiser Normalization

a. Rotation converged in 9 iterations

Examination of the items discovered five common themes of the Teachers' Followership Modalities construct that coincided with Courageous Followership dimensions proposed by Chaleff (1995), namely Assume Responsibility (6 items), To Serve (4 items), To Participate in Transformation (4 items), To Take Moral Action ( 3 items) and To Challenge (3 items). The final EFA results for Teachers' Followership Modalities construct with 20 items is rearrange and tabulated neatly in Table 7. Also, the schematic diagram in Figure 4 shows the second-order construct for each component of Teachers' Followership Modalities.

Table 7. The Final EFA Results for Teachers' Followership Modalities Construct

\begin{tabular}{|c|c|c|c|c|c|c|c|c|}
\hline \multicolumn{9}{|c|}{ Rotated Component Matrix ${ }^{a}$} \\
\hline \multirow{2}{*}{$\begin{array}{c}\text { Comp } \\
0 \\
\text { nent }\end{array}$} & \multirow{2}{*}{$\begin{array}{l}\text { New } \\
\text { Item } \\
\text { Label }\end{array}$} & \multirow{2}{*}{$\begin{array}{l}\text { Item } \\
\text { Labe } \\
\text { I }\end{array}$} & \multirow[b]{2}{*}{ Item Statement } & \multicolumn{5}{|c|}{ Component } \\
\hline & & & & 1 & 2 & 3 & 4 & 5 \\
\hline \multirow{6}{*}{ 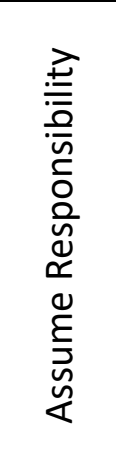 } & AR1 & F1 & Teaching is an important goal for me & .797 & & & & \\
\hline & AR2 & F4 & I reflect on my strengths and weaknesses & .626 & & & & \\
\hline & AR3 & F11 & $\begin{array}{l}\text { My work goals are in line with the school's } \\
\text { goals }\end{array}$ & .602 & & & & \\
\hline & AR4 & F12 & I am committed to my school & .792 & & & & \\
\hline & AR5 & F13 & I am enthusiastic about my work & .837 & & & & \\
\hline & AR6 & F14 & $\begin{array}{l}\text { I actively develop my teaching } \\
\text { competencies so that I become more } \\
\text { valuable to the school }\end{array}$ & .820 & & & & \\
\hline \multirow{4}{*}{ 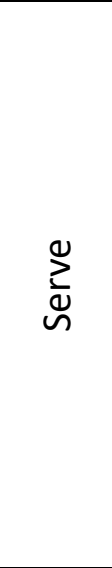 } & S1 & F16 & $\begin{array}{l}\text { When I start a new task at school (e.g., } \\
\text { teaching, project, committee, etc.), I } \\
\text { consider outcomes that are important to } \\
\text { the school }\end{array}$ & & .702 & & & \\
\hline & S2 & F18 & $\begin{array}{l}\text { Even though I may not be the leader of a } \\
\text { project, I continue to contribute to my best } \\
\text { ability }\end{array}$ & & .838 & & & \\
\hline & S3 & F19 & $\begin{array}{l}\text { I help my colleagues, even when I am not } \\
\text { receiving recognition for doing so }\end{array}$ & & .851 & & & \\
\hline & S4 & F20 & $\begin{array}{l}\text { I understand the principal's goals for the } \\
\text { school }\end{array}$ & & .752 & & & \\
\hline \multirow{2}{*}{ 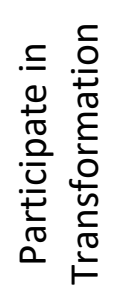 } & PIT1 & F2 & $\begin{array}{l}\text { I independently identify which school } \\
\text { activities are most critical in achieving the } \\
\text { school's goals }\end{array}$ & & & .746 & & \\
\hline & PIT2 & F3 & $\begin{array}{l}\text { I independently think of ideas that will } \\
\text { contribute significantly to the school's } \\
\text { goals }\end{array}$ & & & .781 & & \\
\hline
\end{tabular}


INTERNATIONAL JOURNAL OF ACADEMIC RESEARCH IN PROGRESSIVE EDUCATION AND DEVELOPMENT

Vol. 10, No. 1, 2021, E-ISSN: 2226-6348 @ 2021 HRMARS

\begin{tabular}{|c|c|c|c|c|c|c|}
\hline & PIT3 & F7 & $\begin{array}{l}\text { I help my principal to identify the pros and } \\
\text { cons of ideas }\end{array}$ & 690 & & \\
\hline & PIT4 & F17 & $\begin{array}{l}\text { I take the initiative to pursue tasks beyond } \\
\text { my routine job (e.g., Parent-Teacher } \\
\text { Association) }\end{array}$ & 673 & & \\
\hline \multirow{3}{*}{ 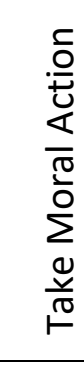 } & $\begin{array}{l}\text { TMA } \\
1\end{array}$ & F5 & $\begin{array}{l}\text { I act based on my own ethical standards } \\
\text { rather than on others' }\end{array}$ & & .717 & \\
\hline & $\begin{array}{l}\text { TMA } \\
2\end{array}$ & F6 & $\begin{array}{l}\text { I try to solve the work-related issues on my } \\
\text { own rather than seek help from my } \\
\text { principal }\end{array}$ & & .711 & \\
\hline & $\begin{array}{l}\text { TMA } \\
3 \\
\end{array}$ & F8 & I ponder my principal's decisions & & .731 & \\
\hline \multirow{3}{*}{ 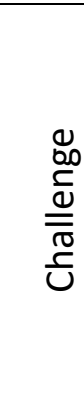 } & $\mathrm{C} 1$ & F9 & $\begin{array}{l}\text { When the principal asks me to do } \\
\text { something that contradicts my professional } \\
\text { preferences, I say "no" rather than "yes" }\end{array}$ & & & .767 \\
\hline & $\mathrm{C} 2$ & F10 & $\begin{array}{l}\text { I assert my views on important issues even } \\
\text { though it may differ from my principal's }\end{array}$ & & & .711 \\
\hline & C3 & F15 & $\begin{array}{l}\text { I can complete a difficult assignment (e.g., } \\
\text { teaching, project, committee, etc.) without } \\
\text { supervision }\end{array}$ & & & .630 \\
\hline \multicolumn{7}{|c|}{$\begin{array}{l}\text { Extraction Method: Principal Component Analysis } \\
\text { Rotation Method: Varimax with Kaiser Normalization } \\
\text { a. Rotation converged in } 9 \text { iterations }\end{array}$} \\
\hline
\end{tabular}




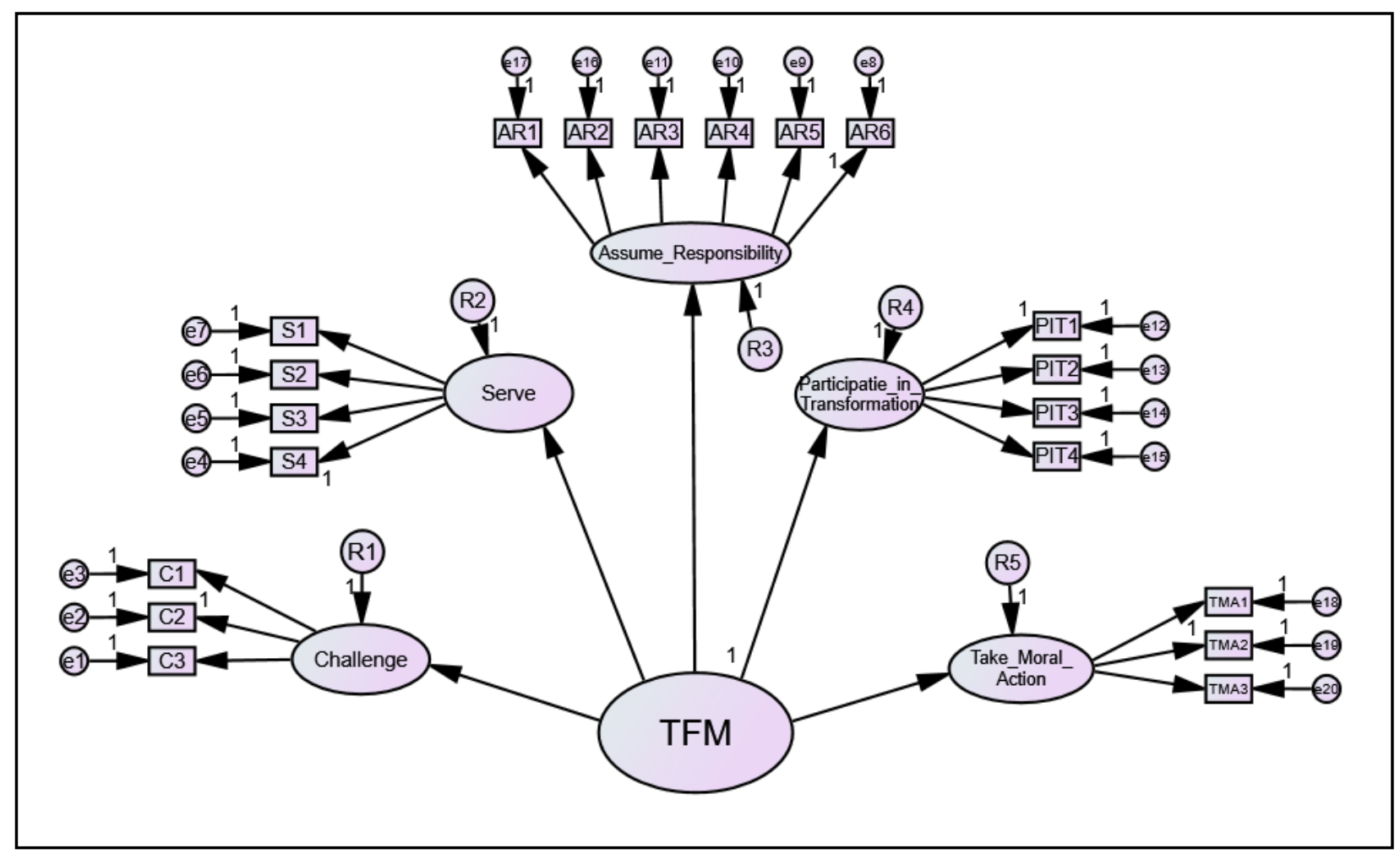

Figure 4. Schematic Diagram for the Second-Order of Teachers' Followership Modalities

\section{Construct}

\section{Reliability Analysis for Teachers' Followership Modalities}

Straub et al. (2004) recommended that reliability should be equal to or above 0.60 for an exploratory or pilot study. Also, Hinton et al. (2014) added four cut-off points, which includes excellent reliability $(>0.90)$, high reliability $(0.70-0.90)$, moderate reliability $(0.50-0.70)$ and low reliability $(<0.50)$. Table 8 indicates that the Cronbach's Alpha values for the five components measuring Teachers' Followership Modalities were ranged from 0.681 to 0.907 . Therefore, the items analyzed in components 1, 2 and 5 have attained excellent internal reliability as their Cronbach's Alpha values greater than 0.90. Meanwhile, Component 3 with a value of 0.802 was highly reliable while Component 4 that scored 0.681 was achieving a moderate reliability level. The overall reliability value for the Teachers' Followership Modalities construct was 0.884 , inferring all the 20 items are strongly reliable and highly acceptable.

Table 8. The Reliability Analysis for Teachers' Followership Modalities Construct

\begin{tabular}{cccc}
\hline No & Name of Component & No of Items & Cronbach's Alpha \\
\hline Component 1 & Assume Responsibility & 6 & 0.904 \\
\hline Component 2 & Serve & 4 & 0.901 \\
\hline Component 3 & Participate in Transformation & 4 & 0.802 \\
\hline Component 4 & Take Moral Action & 3 & 0.681 \\
\hline Component 5 & Challenge & 3 & 0.907 \\
\hline Total & & 20 & 0.884 \\
\hline
\end{tabular}


DEVELOPMENT

Vol. 10, No. 1, 2021, E-ISSN: 2226-6348 @ 2021 HRMARS

\section{Discussions and Conclusions}

This current study aimed to contribute to the existing literature by performing a thorough validation of the dimensions of Teachers' Followership Modalities through the Exploratory Factor Analysis (EFA) procedure. During the early stages of the instrument development process, the researchers have reviewed the questionnaire using the professional feedback of six experts. Besides, the internal consistency for the extracted factors was estimated with Cronbach's Alpha to determine the reliability of the scale. Results from this study revealed that the scale to measure Teachers' Followership Modalities among Malaysian public secondary school teachers has strong reliability and validity.

The Kaiser-Meyer-Olkin (KMO) value of .792 (>.60) illustrated the adequacy of sample used in this study. The sample size of 108 teachers was statistically adequate for conducting a valid EFA (Hair et al., 2010; Bahkia et al., 2019). The findings of the EFA explored that the twodimensional measuring items adapted from Kelley's (1992) Followership Model, namely Independent Critical Thinking and Active Engagement, had collapsed into five components. Based on the EFA results, the five components of the Teachers' Followership Modalities construct had explained $74.376 \%$ (>60\%) of the total explained variance among the items. Meanwhile, the rotated component matrix showed that all 20 items had a factor loading above 0.60 , which met the study's minimum factor loading requirement. This current study, therefore, did not support previous validation studies which reported three factor-solutions in Western literature, such as Blanchard et al. (2009); Gatti et al. (2014); Ligon et al. (2019); and Ribbat et al. (2021). Conversely, this study accomplished a significant benchmark for a five-dimensional structure by retaining all 20 items in the original instrument.

All Cronbach's values in this study have exceeded the acceptable range, indicating that the items in all components measuring the construct have excellent internal reliability, i.e., four out of the five components had high reliabilities (ranged between 0.802 and 0.907 ) while the other was obtaining a moderate reliability value (0.681). This result supported the previous studies (Blanchard et al., 2009; Gatti et al., 2014; Ligon et al., 2019; Rosani \& Tarigan, 2019 and Ribbat et al., 2021) where all the results of Cronbach's Alpha value surpassed the minimum value (.70).

To sum up, the comprehensive development of the measurement and validation processes in this current study has confirmed the internal consistency and reliability of the new Teachers' Followership Modalities scale. Hence, the five-dimensional Teachers' Followership Modalities scale discovered in EFA could adequately assess the capacities needed to be an exemplary follower, particularly among Malaysian public secondary school teachers.

\section{Contributions}

This current study extends the followership literature by identifying the dimensions that constitute Teachers' Followership Modalities, particularly among public secondary school teachers in Malaysia. This study also contributed to the establishment of a validated and reliable measurement scale to assess the construction of the Teachers' Followership Modalities. This validated scale is useful for practitioners as it would increase their awareness to improve the modality of followers in carrying out their day-to-day responsibilities. Moreover, as teachers become more conscious of the factors that influenced their ability to perform and contribute to 
becoming exemplary follower, the instrument will provide them with an opportunity to increase their enthusiasm for carrying out their assigned responsibilities. This scale can therefore be used to determine whether teachers in Malaysian public secondary schools have the capacity to act as exemplary follower and to practice it to the fullest in the realization of the country's educational aspirations.

\section{Limitations and Future Study}

The lack of willingness of teachers to respond to the questionnaire was undoubtedly a major issue during the data collection process. The reasons could be due to the emotionally unstable during the period of the COVID-19 pandemic, in particular, the suspension of schools that prompted an increase in teachers' busy schedules to engage with numerous online classes. Also, this current study used a cross-sectional analysis method that included only a one-time compilation of data over a short period. However, future research should delve into a longerterm analysis of the interventions defined by the teachers' followership modalities in order to fully appreciate how they incorporate positive practices in their day-to-day activities to contribute to their school success as a whole.

Furthermore, this study focused merely on Malaysian public secondary schools and used data from only 108 randomly selected teachers. This drawback can be considered in future studies by looking at different types of Malaysian schools and involving larger samples to see if the same identified and validated measures of Teachers' Followership Modalities found in this study will be reported in other types of schools. Lastly, an extended study involving the use of confirmatory factor analysis is recommended to further validate the existence and contribution of the current factor structure as this may produce a more comprehensive scale of Teachers' Followership Modalities.

\section{Acknowledgment}

The authors wish to express their gratitude to Hadiah Latihan Persekutuan (HLP) and Universiti Malaysia Sarawak (UNIMAS) for funding this research. The authors would also like to convey their appreciation to the public secondary school teachers from the three districts of Sarawak (i.e., Kuching, Padawan and Samarahan) for their support during the data collection. 
INTERNATIONAL JOURNAL OF ACADEMIC RESEARCH IN PROGRESSIVE EDUCATION AND

DEVELOPMENT

Vol. 10, No. 1, 2021, E-ISSN: 2226-6348 @ 2021 HRMARS

\section{References}

Awang, Z. (2012). Research methodology and data analysis. Penerbit Universiti Teknologi MARA Press.

Awang, Z., Afthanorhan, A., Mamat, M., Sultan, U., \& Abidin, Z. (2016). The Likert scale analysis using parametric based Structural Equation Modeling (SEM). Computational Methods in Social Sciences, 4(1), 13-21. https://doi.org/10.5281/zenodo.1299429

Awang, Z., Afthanorhan, W. M. A., \& Asri, M. A. M. (2015). Parametric and non parametric approach in Structural Equation Modeling (SEM): The application of bootstrapping. Modern Applied Science, 9(9), 58-67. https://doi.org/10.5539/mas.v9n9p58

Bahkia, A. S., Awang, Z., Afthanorhan, A., Ghazali, P. L., \& Foziah, H. (2019). Exploratory factor analysis on occupational stress in context of Malaysian sewerage operations. AIP Conference Proceedings, 2138(August). https://doi.org/10.1063/1.5121111

Bartlett, M. S. (1950). Tests of significance in factor analysis. British Journal of Statistical Psychology, 3(2), 77-85. https://doi.org/10.1111/j.2044-8317.1950.tb00285.x

Benson, E. D. (2018). How Followers Are Creating Change and Changing Leaders.

Blair, B. A., \& Bligh, M. C. (2018). Looking for Leadership in All the Wrong Places: The Impact of Culture on Proactive Followership and Follower Dissent. Journal of Social Issues, 74(1), 129-143. https://doi.org/10.1111/josi.12260

Blanchard, A. L., Welbourne, J., Gilmore, D., \& Bullock, A. (2009). Followership styles and employee attachment to the organization. The Psychologist-Manager Journal, 12(2), 111131. https://doi.org/10.1080/10887150902888718

Brislin, R. W. (1970). Back-translation for cross-cultural research. Journal of Cross-Cultural Psychology, 1(3), 185-216. https://doi.org/10.1177/135910457000100301

Carsten, M. K., Uhl-Bien, M., \& Huang, L. (2018). Leader perceptions and motivation as outcomes of followership role orientation and behavior. Leadership, 14(6), 731-756. https://doi.org/10.1177/1742715017720306

Cattell, R. (1966). The Scree Test for the number of factors. Multivariate Behavioral Research, 1(2), 245-276. https://doi.org/10.1207/s15327906mbr0102_10

Chaleff, I. (2009). The Courageous Follower: Standing Up to and for Our Leaders (3rd Editio). Berrett-Koehler Publishers.

Chaleff, I. (2016). In Praise of Followership Style Assessments. Journal of Leadership Studies, 10(3), 45-48. https://doi.org/10.1002/jls.21490

Clarke, M., Killeavy, M., \& Ferris, R. (2015). Mentor teachers as leaders and followers in schoolbased contexts in the Republic of Ireland. International Journal of Educational Management, 29(3), 368-379. https://doi.org/10.1108/IJEM-09-2013-0142

Creswell, J. W., \& Guetterman, T. C. (2019). Educational Research: Planning, Conducting, and Evaluating Quantitative and Qualitative Research (6th Edition). Pearson.

Crossman, B., \& Crossman, J. (2011). Conceptualising followership - a review of the literature. Leadership, 7(4), 481-497. https://doi.org/10.1177/1742715011416891

Dahl, $\varnothing ., \&$ Kongsvik, T. (2018). Safety climate and mindful safety practices in the oil and gas industry. Journal of Safety Research, 64, 29-36. https://doi.org/10.1016/j.jsr.2017.12.009

Gaskin, C. J., \& Happell, B. (2014). On exploratory factor analysis: A review of recent evidence, an assessment of current practice, and recommendations for future use. International 
INTERNATIONAL JOURNAL OF ACADEMIC RESEARCH IN PROGRESSIVE EDUCATION AND

DEVELOPMENT

Vol. 10, No. 1, 2021, E-ISSN: 2226-6348 @ 2021 HRMARS

Journal of Nursing Studies, 51(3), 511-521. https://doi.org/10.1016/j.ijnurstu.2013.10.005

Gatti, P., Tartari, M., Cortese, C. G., \& Ghislieri, C. (2014). A contribution to the italian validation of kelley's followership questionnaire. TPM - Testing, Psychometrics, Methodology in Applied Psychology, 21(1), 67-87. https://doi.org/10.4473/TPM21.1.5

Ghias, W., \& Hassan, S. (2018). Does Courageous Followership contribute to Exemplary Leadership Practices: Evidence from Pakistan? International Journal of Business \& Management, 13(June), 10-21. https://doi.org/10.13140/RG.2.2.13212.80009

Gorsuch, R. L. (1990). Common Factor Analysis versus Component Analysis: Some Well and Little Known Facts. Multivariate Behavioral Research, 25(1), 33-39. https://doi.org/10.1207/s15327906mbr2501_3

Hair, J. F., Anderson, R. E., Tatham, R. L. and, \& Black, W. C. (2010). Multivariate Data Analysis: A Global Perspective (7th Edition). Pearson Prentice Hall.

Hair, J. F., Black, W. C., Babin, B. J., \& Anderson, R. E. (2014). Multivariate Data Analysis_7th Edition. Pearson. https://doi.org/10.4324/9781351269360

Hair, J. F., Black, W. C., Babin, B. J., \& Anderson, R. E. (2019). Multivariate Data Analysis_Eighth Edition. CENGAGE INDIA.

Hair, J. F., Celsi, M., Money, A., Samouel, P., \& Page, M. (2015). The Essentials of Business Research Methods: Third Edition. Taylor and Francis Inc. https://doi.org/10.4324/9781315716862

Heale, R., \& Twycross, A. (2015). Validity and reliability in quantitative studies. Evidence-Based Nursing, 18(3), 66-67. https://doi.org/10.1136/eb-2015-102129

Hinić, D., Grubor, J., \& Brulić, L. (2017). Followership styles and job satisfaction in secondary school teachers in serbia. Educational Management Administration and Leadership, 45(3), 503-520. https://doi.org/10.1177/1741143215623787

Hinton, P. R., McMurray, I., \& Brownlow, C. (2014). SPSS Explained, Second Edition. Routledge Inc. https://doi.org/10.4324/9781315797298

Hoque, A. S. M. ., Siddiqui, B. A., Awang, Z., \& Baharu, S. M. A. . (2018). Exploratory Factor Analysis of Enterpreneurial Orientation in the Context of Bangladeshi Small and Medium Enterprises (SMEs). European Journal of Management and Marketing Studies, 3(2), 81-94. https://doi.org/10.5281/zenodo.1292331

Huff, C., \& Tingley, D. (2015). "Who are these people?" Evaluating the demographic characteristics and political preferences of MTurk survey respondents. Research and Politics, 2(3), 1-12. https://doi.org/10.1177/2053168015604648

Hulin, C., Netemeyer, R., \& Cudeck, R. (2001). Can a Reliability Coefficient Be Too High? Journal of Consumer Psychology, 10(1), 55-58. https://doi.org/https://www.jstor.org/stable/1480474

Kaiser, M. O. (1974). Kaiser-Meyer-Olkin measure for identity correlation matrix. Journal of the Royal Statistical Society, 52, 296-298.

Kelley, R. E. (1988). In Praise of Followers. 66(6), 142-148. http://www.kquattrin.com/uploads/2/5/8/7/25876455/kelley_1988.pdf

Kelley, R. E. (1992). The power of followership: How to create leaders people want to follow, and followers who lead themselves. Doubleday.

Khan, S. N., Busari, A. H., \& Abdullah, S. M. (2018). The Essence of Followership: Review of the 
INTERNATIONAL JOURNAL OF ACADEMIC RESEARCH IN PROGRESSIVE EDUCATION AND

DEVELOPMENT

Vol. 10, No. 1, 2021, E-ISSN: 2226-6348 @ 2021 HRMARS

Literature and Future Research Directions (Issue October, pp. 148-170).

https://doi.org/10.4018/978-1-5225-4996-3.ch006

Khan, S. N., Busari, A. H., \& Abdullah, S. M. (2019). The Essence of Followership: Review of the Literature and Future Research Directions. In Mughal, Y. H., \& Kamal, S. (Ed.), Servant Leadership Styles and Strategic Decision Making (pp. 148-170). IGI Global. https://doi.org/10.4018/978-1-5225-4996-3.ch006

Ligon, K. V, Stoltz, K. B., \& Rowell, R. K. (2019). An Empirical Investigation of the Kelley Followership Questionnaire Revised. The Journal of Leadership Education, 18(3), 97-112. https://doi.org/10.12806/V18/I3/R7

Livingston, S. A. (2018). Test Reliability - Basic Concepts (Issue January). Research Memorandum ETS RM-18-01. https://doi.org/Retrieved from https://www.ets.org/Media/Research/pdf/RM-18-01.pdf

MacCallum, R. C., Widaman, K. F., Zhang, S., \& Hong, S. (1999). Sample size in factor analysis. Psychological Methods, 4(1), 84-99. https://doi.org/10.1037/1082-989X.4.1.84

Mahfouz, S. A., Awang, Z., \& Muda, H. (2019). The impact of transformational leadership on employee commitment in the construction industry. International Journal of Innovation, Creativity and Change, 7(10), 151-167.

Meyers, L. S., Gamst, G., \& Guarino, A. J. (2013). Applied multivariate research: Design and interpretation (2nd Edition). SAGE Publications, Inc.

Muda, H., Baba, Z. S., Awang, Z., Badrul, N. S., Loganathan, N., \& Ali, M. H. (2020). Expert review and pretesting of behavioral supervision in higher education. Journal of Applied Research in Higher Education, 12(4), 767-785. https://doi.org/10.1108/JARHE-02-2019-0029

Nunnally, J. C. (1978). Psychomtietric theory. McGraw-Hill, New York.

Nunnally, J. C., \& Bernstein, I. H. (1994). Psychometric Theory, 3rd Edition. McGraw-Hill, Inc.

Oluwatayo, J. A. (2012). Validity and Reliability Issues in Educational Research. Journal of Educational and Social Research, 2(2), 391-400.

https://doi.org/10.5901/jesr.2012.v2n2.391

Pallant, J. (2016). SPSS Survival Manual: A step by step guide to data analysis using SPSS program. McGraw-Hill, Inc.

http://www.fao.org/tempref/AG/Reserved/PPLPF/ftpOUT/Gianluca/stats/SPSS.Survival.M anual.ISBN.0-335-20890-8.pdf

Pett, M. A., Lackey, N. R., \& Sullivan, J. J. (2003). Making Sense of Factor Analysis: The Use of Factor Analysis for Instrument Development in Health Care Research. SAGE Publications, Inc.

Polit, D. F., Beck, C. T., \& Hungler, B. P. (2001). Essentials of Nursing Research: Methods, Appraisal and Utilization. 5th Edition. Philadelphia: Lippincott Williams \& Wilkins.

Rahlin, N. A., Awang, Z., Afthanorhan, A., \& Aimran, N. (2019). The art of covariance based analysis in behaviour-based safety performance study using confirmatory factor analysis: Evidence from SMES. International Journal of Innovation, Creativity and Change, 7(10), 351-370.

Ribbat, M., Krumm, S., \& Hüffmeier, J. (2021). Validation of a German Version of Kelley's (1992) Followership Questionnaire. Psychological Test Adaptation and Development, 1-13. https://doi.org/10.1027/2698-1866/a000005 
INTERNATIONAL JOURNAL OF ACADEMIC RESEARCH IN PROGRESSIVE EDUCATION AND

DEVELOPMENT

Vol. 10, No. 1, 2021, E-ISSN: 2226-6348 @ 2021 HRMARS

Rosani, S. A., \& Tarigan, M. (2019). Validasi Instrumen Followership Model Kelley Versi Indonesia. Jurnal Psikologi Insight, 3(2), 70-79.

Rovai, A. P., Baker, J. D., \& Ponton, M. K. (2014). Social science research design and statistics: A practitioner's guide to research methods and IBM SPSS analysis. Chesapeake, VA. Watertree Press LLC.

Sekaran, U., \& Bougie, R. (2016). Research Methods for Business 7th Edition: A Skill-Building Approach. Wiley \& Sons Ltd. https://doi.org/10.1007/978-94-007-0753-5_102084

Straub, D., Boudreau, M.-C., \& Gefen, D. (2004). Validation Guidelines for IS Positivist Research. Communications of the Association for Information Systems, 13(24), 380-427. https://doi.org/10.17705/1cais.01324

Tabachnick, B. G., \& Fidell, L. S. (2013). Using multivariate statistics, 6th Edition. Pearson.

Taherdoost, H. (2016a). How to Design and Create an Effective Survey/Questionnaire; A Step by Step Guide. International Journal of Academic Research in Management (IJARM), 5(4), 3741.

Taherdoost, H. (2016b). Validity and Reliability of the Research Instrument: How to Test the Validation of a Questionnaire/Survey in a Research. International Journal of Academic Research in Management (IJARM), 5(3), 28-36. https://doi.org/10.2139/ssrn.3205040

Triandis, H. C., \& Brislin, R. W. (1984). Cross-cultural psychology. American Psychologist, 39(9), 1006-1016. https://doi.org/10.1037/0003-066X.39.9.1006

Uhl-Bien, M., \& Arena, M. (2018). Leadership for organizational adaptability: A theoretical synthesis and integrative framework. Leadership Quarterly, 29(1), 89-104. https://doi.org/10.1016/j.leaqua.2017.12.009

Uhl-Bien, M., Riggio, R. E., Lowe, K. B., \& Carsten, M. K. (2014). Followership theory: A review and research agenda. Leadership Quarterly, 25(1), 83-104.

https://doi.org/10.1016/j.leaqua.2013.11.007

Van Teijlingen, E. R., \& Hundley, V. (2002). The importance of pilot studies. Nursing Standard, 16(40), 33-36. https://doi.org/10.7748/ns2002.06.16.40.33.c3214

Williams, B., Onsman, A., \& Brown, T. (2010). Exploratory factor analysis: A five-step guide for novices. Journal of Emergency Primary Health Care, 8(3), 1-13.

https://doi.org/10.33151/ajp.8.3.93

Yahaya, T. A. B., Idris, K., Suandi, T., \& Ismail, I. A. (2018). Adapting instruments and modifying statements: The confirmation method for the inventory and model for information sharing behavior using social media. Management Science Letters, 8(5), 271-282.

https://doi.org/10.5267/j.msl.2018.4.021

Yong, A. G., \& Pearce, S. (2013). A Beginner's Guide to Factor Analysis: Focusing on Exploratory Factor Analysis. Tutorials in Quantitative Methods for Psychology, 9(2), 79-94. https://doi.org/10.20982/tqmp.09.2.p079 